\title{
ASPEK HUKUM PENILAIAN HARGA YANG WAJAR DALAM PERTUKARAN BARANG
}

\author{
Henry Donald Lumbantoruan ${ }^{1}$
}

\begin{abstract}
One of the main principles to ensure economic transactions more efficient and effective is the principle of justice felt by the economic actors. The principle of justice can only be realized if each economic actor mutually agreed upon value (value) of goods and services as well as the currency unit in every economic transaction. In other words, the exchange of (exchange) would not happen if there is no agreement on the value of the underlying economic exchange. In this case, efficient or not an economic system will be determined by how objects are interchangeable assessed. Conditions 'over-valued' or 'under-valued' of object-exchange will certainlymake the transaction does not run efficiently and optimally. Conditions 'over-valued' will be very detrimental to consumers and profitable producer or seller. The difference in prices due to 'over-valued' is a reflection of the inefficiency of an economy, because consumers should get cheaper products and services. Exchange process in a transaction that took place between economic actors was based on the agreement the fair value of the goods and services both private and state. Fair value (fair value) is basically a reflection of the market value (Market value) of assets. When the fair value opinion generated by the Valuer carried out correctly, of course, will increase improve the quality of financial statements. This is because the value of corporate assets truly reflect the conditions (market value) up to date, so that the company's assets will not be reported undervalued or overvalued. The problem is, until now we have not had conditions governing special assessment. No new judging partially regulated in the Capital Market Law, Banking and Insurance. In the case there are still many areas that need adjustment of business judgment. The question is, what arrangements benefit assessment?
\end{abstract}

\section{Kata kunci: Aspek Hukum Penilaian Harga Wajar}

\section{PENDAHULUAN}

Salah satu prinsip transaksi ekonomi yang efisien dan efektif adalah prinsip keadilan yang dirasakan oleh para aktor ekonomi. Prinsip keadilan ini dapat terwujud bila pelaku ekonomi sepakat atas nilai ( $v a-$ lue) dari barang dan jasa serta satuan mata uang dalam setiap transaksi ekonomi. Dalam hal ini, efisien tidaknya suatu sistem ekonomi akan ditentukan oleh bagaimana obyek yang dipertukarkan dinilai. Kondisi 'over-valued' atau 'under-valued' dari obyek-pertukaran tentu akan membuat transaksi tidak berjalan secara efisien dan optimal.

Kondisi 'over-valued' dapat merugikan konsumen dan menguntungkan pihak penjual. Selisih harga akibat 'over-valued' merupakan cerminan ketidakefisienan

\footnotetext{
${ }^{1}$ Peneliti Pada Badan Pembinaan Hukum Nasional Kementerian Hu-
} kum dan Hak Asasi Manusia (Kemenkum-HAM) RI suatu perekonomian, karena konsumen seharusnya mendapatkan produk dan jasa lebih murah. Dalam perekonomian, selisih harga normal dengan 'over-valued'. Di sisi lain, kondisi 'under-valued' akan merugikan produsen dan penjual. Dimana seharusnya barang dan jasa dihargai lebih tinggi, karena suatu hal maka harga yang didapat di bawah biaya produksi.

Dalam perekonomian modern, aktivitas ekonomi telah berkembang menjadi sangat beragam. Dalam industri keuangan seperti perbankan, asuransi, pasar modal dan pasar uang, transaksi ekonomi menjadi lebih kompleks dan rumit. Transaksi dalam indus- tri keuangan sangat mengandalkan pada mekanisme kontrak (contractual based) dimana masing-masing pihak setuju dan sepakat melakukan pertukaran berdasarkan 'nilai' yang disepakati bersama.

Pertukaran juga dilakukan oleh entitas non-badan usaha dimana tujuan mengejar keuntungan (pro- 
fit) bukanlah tujuan utama seperti pemerintah pusat dan daerah, Lembaga swadaaya Masyarakat, museum dan organisasi kemasyarakatan lainnya. Meskipun begitu, organisasi pemerintah dan sosial tidak menutup kemungkinan melakukan pertukaran yang melibatkan satuan ekonomis. Oleh karena itu, pemahaman tentang 'nilai' atas obyek yang dipertukarkan juga akan menjamin efisiensi dan efektivitas pertukaran dan transaksi lembaga-lembaga tersebut. Kondisi 'over-valued' dan 'under-valued' juga merugikan jenis lembaga ini.

Satuan tukar, dalam bentuk-bentuk mata uang, merupakan ukuran atas nilai yang disepakati. Baik barang, produk, jasa, harapan imbal balik, keuntungan dan kerugian didasarkan pada satuan nilai tukar yang disepakati. Nilai yang wajar merupakan keseimbangan (equilibrium) antar pihak sesuai kaidah efisiensi dan efektivitas. Proses penentuan suatu nilai dimulai dari adanya obyek yang dinilai, proses penilaian dan output penilaian. Proses ini dapat terjadi secara sederhana sampai ke proses yang rumit, panjang dan kompleks.

Proses pertukaran dalam transaksi yang terjadi diantara aktor ekonomi tersebut dilandasi atas kesepakatan nilai wajar terhadap produk barang dan jasa baik swasta maupun negara. Masalahnya, sampai saat ini kita belum mempunyai ketentuan yang me- ngatur penilaian secara khusus. Baru ada penilaian yang diatur secara parsial dalam Undang-undang Pa- sar Modal, Perbankan dan Asuransi. Pada hal masih banyak bidang-bidang usaha yang perlu pengaturan penilaiannya. Untuk memperlancar mekanisme dan prosedur pertukaran dalam proses penilaian diperlukan suatu aturan yang bisa mengakomodir berbagai kepentingan.

Oleh karena itu, ketiadaan peraturan mengenai penilaian barang dan jasa, berpotensi merugikan negara dan masyarakat. Sebab, penentuan harga yang disepakati atas barang dan jasa tidak didasarkan pada hasil penilaian oleh lembaga independen yang ditunjuk untuk itu, melainkan hanya berdasarkan kesepakatan. Sehingga, sering menjadi permasalahan karena nilai yang disepakati tersebut tidak mencerminkan harga wajar bahkan tidak sesuai dengan harga pasar terutama terjadi pada aset-aset negara.

\section{PERMASALAHAN}

Memahami hal tersebut diatas, maka Permasalahan dalam tulisan ini adalah sebagai berikut: Bagaimana Pengaturan secara hukum mengenai Penilaiaan harga wajar dari Pertukaran barang.

\section{TUJUAN PENULISAN}

Untuk Mengetahui Pengaturan mengenai Penilaian harga wajar dari Pertukaran Barang.

\section{SEJARAH PERKEMBANGAN PENILAIAN HARGA.}

Dari perspektif keilmuan, teori penilaian merupakan suatu bentuk pengembangan pragmatis dari Teori Ekonomi yang berkaitan dengan nilai dan harga. ${ }^{2}$ Teori ini semula diperkenalkan oleh Alfred Marshall (1842-1924), ekonom Inggris mazhab neoklasik. Konsepnya mencakup penentuan nilai properti berdasarkan kapitalisasi pendapatan, pengaruh depresiasi atas bangunan dan tanah, pengaruh dari berbagai tipe bangunan dan penggunaan tanah atas nilai tanah. Marshall juga dikenal sebagai tokoh yang memperkenalkan 3 (tiga) pendekatan penilaian tradisional, yaitu market (sales) comparison (perbandingan data pasar), replacement cost (biaya), dan income capitalisation (kapitalisasi pendapatan). Selanjutnya Irving Fisher (1867-1947) mengembangkan teori pendapatan dari nilai (income theory of value) yang merupakan dasar dari metode kapitalisasi pendapatan yang digunakan dalam penilaian modern.

J.F.N. Murray dalam "Principles and Practice of Valuation" meyakini bahwa penilaian telah dipraktekkan oleh para penilai selama berabad-abad dan istilah penilaian telah dikenal sejak awal abad pertengahan. Di lain pihak, banyak pula yang berpendapat bahwa penilaian merupakan suatu aktivitas profesional dalam dunia komersial yang muncul pada era modern. Faktor pendorong eksistensi penilaian sebagai profesi antara lain adalah sejak diterapkannya paham

\footnotetext{
${ }^{2}$ J.F.N. Murray dalam John L. Cooper, Course-packet Modul 2 on Indonesia-Australia Training Specialist Phase II AusAID, Workshop on Asset Appraisal for Financial Restructuring, Jakarta, 2002. hal. 2 yang dalam versi aslinya menyebutkan: "The theory of valuation is a pragmatic extension of economic tehories relating to value and price, but it is remarkable to find that there is an almost complete dissociation between economic theory and the theory of valuation" ( $p$ 82)
} 
kapitalisme, adanya peningkatan urbanisasi terutama sebagai akibat dari revolusi lndustri dan pertanian di Eropa, dan pesatnya pertumbuhan pada sektor keuangan dalam perekonomian negara industri maju. ${ }^{3}$

Penilaian di Indonesia telah ada sejak era kolonial yang dikenal dengan klasiran. Pekerjaannya menilai tanah pertanian, sawah, kebun dan ditujukan untuk tujuan perpajakan. Pada masa-masa selanjutnya, Penilai berkiprah di instansi pemerintah namun selain untuk tujuan perpajakan, Penilai juga berkiprah di instansi lain sebagai juru taksir pada instasi pegadaian dan lelang pada Kantor Lelang Negara. Mantri Klasir berfungsi sebagai Penilai untuk tujuan perpajakan sekaligus berfungsi sebagai Land Surveyor, karenanya mereka juga berpredikat sebagai Mantri Ukur.

Profesi penilai dimulai sejak tahun 1961 berdasarkan UU no 20 tahun 1961 tentang pecabutan hak atas tanah. Secara formal profesi penilai mulai ada di Indonesia sejak tahun 1970, dimana banyak penilai dari Philipina bekerja sama dengan para tenaga ahli dari Indonesia untuk melakukan penilaian-penilaian untuk kepentingan perbankan pada saat itu. Pada tahun 1980 didirikan asosiasi perusahaan penilai yang dikenal sebagai Gabungan Perusahaan Penilai (GAPPI). Penilai yang telah bergabung di GAPPI tersebut melakukan pekerjaan penilai dan bekerjasama dengan Departemen Keuangan khusus untuk penilaian Pajak Bumi dan Bangunan.

Pada tahun 1981 didirikan Masyarakat Asosiasi Profesi Penilai Indonesia (MAPPI), Yang merupakan organisasi profesi bagi para Penilai dan pihakpihak yang terkait dengan bidang penilaian dalam arti luas. Sejalan dengan itu, ruang lingkup kegiatan Penilai di Indonesia saat ini berdasarkan Peraturan Menteri Keuangan No: 125/PMK.01/2008 tentang Jasa Penilaian Publik: 1). Penilaian untuk menentukan nilai ekonomis terhadap harta benda berwujud maupun yang tidak berwujud yaitu Penilaian Aktiva tetap; dan Penilaian Usaha trademark dan hak pa- ten; 2). Penilaian Proyek; 3). Penilaian Kelayakan Teknis; 4). Penilaian dan Konsultasi Pengembangan termasuk Studi Kelayakan Proyek; 5). Penilaian dan Pengawasan Proyek ; 6). Penilaian dan Konsulta-

\footnotetext{
${ }^{3}$ Cooper., John L., Course-packet Modul 2 on Indonesia-Australia Training Specialist Phase II AusAID, Workshop on Asset Appraisal for Financial Restructuring, Jakarta, 2002. hal. 2
}

si Investasi; 7). Penilaian dan Teknologi Informasi di bidang Properti; 8). Penilaian Konsultasi Proper, termasuk kegiatan Konsultasi keuangan Properti; atau 9). Pengelolaan Harta Benda.

Sejak kegiatan investasi mulai berkembang pada tahun 70-an seiring dengan meningkatnya kegiatan investasi, maka profesi penilai mulai dikenal di Indonesia sejak pelaksanaan Pelita I. Melihat perkembangan ini dan untuk memberikan kepastian hukum dan berusaha bagi pengusaha, maka 7 tahun kemudian diterbitkan Keputusan Menteri Perdagangan No.161/ Kp/1977 yang mengatur perizinan usaha penilai di Indonesia. Pada masa tersebut, lembaga yang paling umum menggunakan jasa penilai adalah bank dalam kaitannya untuk menentukan nilai agunan kredit. Pada dekade berikutnya 1980-1990, perkembangan jasa penilai semakin pesat meliputi berbagai ruang lingkup kegiatan. Objek penilaian juga telah mencakup sebagian besar jenis aset/properti, baik yang sifatnya komersil maupun non komersil, berwujud (tangible) maupun tidak berwujud (intangible).

\section{PENGERTIAN PENILAIAN.}

Dalam kamus "The Dictionary of Real Estate Appraisal" mendefinisikan Penilaian sebagai "the act or process of estimating value". Menurut Webster Dictionary, Penilaian dimaksudkan sebagai "an estimated value set upon property". Di dalam kamus umum Bahasa Inggris-Bahasa Indonesia, Appraisal diartikan sebagai Penilaian atau penaksiran, demikian juga $V a-$ luation diartikan sebagai penilaian atau penaksiran.

Selanjutnya Financial Institution Reform, Recovery, and Enforcement Act of 1989 (FIRREA) atau semacam Undang-undang di Amerika Serikatmendefinisikan Penilaian sebagai: "a written statement used in connection with federally related transaction that is independently and impartially prepared by a licensed or certified apparaiser setting forth an opinion of defined value of an adequately described property as of a specific date, supported by presentation and analysis of relevant market information". Kemudian, Penilaian juga didefinisikan oleh Uniform Standard of Professional Appraisal Practice (USPAP) di Amerika Serikat sebagai "the act or process of estimating value; an estimate of value of, or pertaining to appraising and related functions; e.g.:appraisal practice, appraisal services". 
Terdapat dua istilah dalam bahasa asing mengenai penilaian atau penaksiran yaitu Appraisals dan Valuation, sehingga sekilas keduanya mempunyai maksud yang kurang lebih sama. Namun di lnggris dan negara anggota persemakmuran (commonwealth countries), istilah appraisal lebih ditujukan kepa- da pelaksanaan penaksiran yang keterampilannya berada dibawah keterampilan untuk melaksanakan valuation mengingat untuk malaksanakan valuation dipersyaratkan adanya keahlian khusus secaraformal yang harus disertifikasi. Di Amerika Serikat, istilah appraisal dan valuation mempunyai arti yang sama, namun istilah Appraisal dan Appraiser lebih banyak dipergunakan di Amerika Serikat, sedangkan istilah Valuation dan Valuers biasa dipakai di lnggris dan negara anggota persemakmuran.

Meskipun terdapat dua istilah yang sama, tetapi satu sama lain tidak dapat dipisahkan, yaitu pengertian valuer dan nilai. Dari beberapa definisi tersebut di atas, yang dapat digaris bawahi mengenai Penilaian adalah: a. Penilaian merupakan sebuah opini (anopinion bukan judgment; b. Penilaian juga merupakan suatu estimasi nilai (an estimated value); c. Dilakukan pada hari yang ditentukan (as of specific date); d. Berdasarkan kepada hasil analisis atas data pasar yang relevan (based on analysis of relevan market information).

\section{PENGERTIAN NILAI, BIAYA DAN HARGA}

Pengertian istilah di atas perlu dipahami dalam bidang penilaian karena sering dan mudah sekali tertukar mengingat wujud pengungkapannya untuk figur suatu objek dalam mata uang. Definisi Biaya adalah sejumlah uang yang dikeluarkan dalam pembuatan atau pembangunan suatu properti (Biaya = biaya material + biaya perijinan + upah pembuat/pekerja/tukang/buruh + biaya tidak langsung lain-lainnya).

Definisi Harga adalah sejumlah uang yang disepakati dalam karena suatu transaksi atau pertukaran suatu barang yang terjadi dalam pasar, dimana penjual dan pembeli mempunyai pengetahuan yang layak mengenai fakta-fakta yang relevan dan lepas sama sekali dari paksaan. $($ Harga $=$ Biaya + Keuntungan yang ditetapkan oleh produsen \& keadaan pasar).

Definisi Nilai pada umumnya adalah klaim dalam bentuk uang terhadap semua hak atas harapan keuntungan yang akan datang, baik yang berwujud maupun yang tidak berwujud yang timbul karena pemilikan suatu properti. Dalam suatu penilaian, seorang penilai akan mencari berapa sebenarnya nilai dari harta tersebut.

Dalam beberapa hal yang membatasi pengertian dasar nilai adalah adanya perbedaan penafsiran dalam jumlah nilai uang untuk suatu harta tetap yang sama. Nilai bukanlah karakter dari suatu properti itu sendiri, namun ia tergantung dari kehendak manusia. Nilai suatu properti adalah subyektif dan berlainan bagi seseorang, sebagaimana kehendak manusia yang juga berbeda dari waktu ke waktu. Suatu properti akan mempunyai nilai bila properti tersebut mempunyai kegunaan bagi manusia. Pendekatan yang digunakan dalam melakukan penilaian yaitu: Metode Perbandingan Data Pasar; Nilai diindikasikan oleh penjualan baru-baru ini atas properti serupa di pasar; Metode Kalkulasi Biaya (Cost Approach). Nilai adalah biaya saat ini yang diperlukan untuk memproduksi kembali/menggantikan bangunan yang ada, dikurangi dengan berkurangnya nilai akibat depresiasi ditambah dengan nilai tanah dari lokasi tersebut; Metode Kapitalisasi Pendapatan (Income Approach); Nilai merupakan kemampuan dari properti untuk menghasilkan, yang didasarkan pada kapitalisasi pendapatan

\section{KONSEP DAN PRINSIP PENILAIAN}

Sejalan dengan Penilaian harga barang, maka hal itu dapat di lihat dari segi konsep penilaian yang terdiri dari:

\section{a. Konsep Sewa Tanah}

Salah satu konsep yang paling tua tentang nilai didasarkan pada pengamatan terhadap tanah pertanian di Eropa yang dilakukan oleh Von Thunen pada sekitar abad ke 17. Asumsi yang mendasari pandangan ini adalah bahwa tanah akan menghasilkan keuntungan dari produksinya atau sewa, dimana keuntungan ini akan lebih besar apabila dihasilkan produk yang lebih tinggi nilainya dan meningkatkan intensifikasi penggunaan tanah. Oleh karena adanya keuntungan yang bervariasi tersebut, siapa yang mampu menghasilkan produk dengan nilai tinggi selalu memenangkan persaingan. Faktor lain yang mempengaruhi harga tanah adalah biaya transportasi produk menuju pasar, dengan demikian keuntungan lebih besar akan diperoleh apabila lokasi tanah lebih dekat dengan lokasi pasar. Berdasarkan kenyataan tersebut dapat dihasilkan be- 
berapa konsep nilai tanah, antara lain adalah:

- Keuntungan atas penggunaan tanah yang intensif (Intensive Margin) merupakan jarak dimana penggunaan tertentu atas tanah lebih baik dari jenis penggunaan lainnya.

- Keuntungan atas ekstensifikasi penggunaan tanah (Extensive Margin) merupakan jarak dimana penggunaan tanah untuk aktivitas tertentu diluarnya akan menjadi tidak menguntungkan.

- Grafik Gadai Sewa (Bid Rent Curve) merupakan kecenderungan menurunnya nilai tanah akibat semakin jauhnya jarak dari pasar, dan menjadi layak untuk penggunaan tanah yang menghasilkan keuntungan lebih kecil.

Salah satu dasar utama dari seluruh konsep nilai yaitu peranan "lokasi" yang pada umumnya di indikasikan oleh kenyataan bahwa nilai tanah tertinggi di satu wilayah pada umumnya terdapat pada loka- si yang paling mudah dicapai dari segala penjuru, umumnya berada dekat dengan pusat kota. Pemikiran yang mendasari konsep ini adalah setiap saat tanah, mempunyai potensi untuk menghasilkan pendapatan dan memberikan keuntungan kepada pengguna tanah tersebut. Pada terminologi klasik, nilai tanah merupakan nilai kini dan seluruhan keuntungan dan manfaat di masa mendatang yang dihasilkan oleh tanah tersebut dikenakan diskon pada tingkat yang sesuai untuk memberikan keuntungan atas investasi danuntuk menampung resiko yang timbul akibat investasi tanah. Konsep ini merupakan dasar dari metode Kapitalisasi Pendapatan untuk menentukan nilai properti. Dalam konsep ini waktu mempunyai pengaruh besar terhadap nilai suatu investasi.

\section{b. Konsep Utilitas}

Pandangan mengenai kemanfaatan hukum dalam teori legal utilitarisme yang dipelopori oleh Jeremy Bentham (1748-1832) mengatakan bahwa hukum barulah dapat diakui sebagai hukum, jika ia memberikan kemanfaatan yang sebesar-besarnya terhadap sebanyak-banyaknya orang. ${ }^{4}$ Bagi Jeremy Bentham, tujuan perundang-undangan adalah untuk menghasilkan kebahagiaan bagi masyarakat. Untuk itu pe-

\footnotetext{
${ }^{4}$ Achmad Ali, Menguak Teori Hukum (Legal Theory) \& Teori Peradilan (Judicialprudence): Termasuk Interpretasi Undang-Undang (Legisprudence) Volume I Pemahaman Awal, Jakarta: Kencana, 2009, hal. 76
}

rundang-undangan harus berusaha untuk mencapai empat tujuan: a. to provide subsistence (untuk memberi nafkah hidup); b. to provide abundance (untuk memberikan makanan yang berlimpah); c. toprovide security (untuk memberikan perlindungan); d. to attain equility (untuk mencapai persamaan). ${ }^{5}$ Pandangan Jeremy Bentham teori legal utilitarisme dimaksudkan bahwa dalam pembentukan peraturan perundang-undangan seperti Undang-Undang Penilaian harus dapat memberikan kemanfaataan (utility) yang optimal bagi seluruh masyarakat, sehingga tidak ada yang dirugikan.

Sementara itu, konsep Analisis Ke- Ekonomian Hukum (AKH), oleh Posner mengatakan bahwa Pendekatan dan penggunaan analisis ini harus disusun dengan pertimbangan-pertimbangan ekonomi dengan tidak menghilangkan unsur keadilan, sehingga keadilan dapat menjadi economic standard yang didasari oleh tiga elemen dasar, yaitu nilai (value), kegunaan (utility), dan efisiensi (efficiency) yang didasari oleh rasionalitas manusia. ${ }^{6}$ Berdasarkan konsep dasar ini, AKH yang dikembangkan oleh Posner kemudian dikenal dengan the economic conception of justice, dengan simpulan bahwa hukum diciptakan dan diaplikasikan untuk tujuan utama meningkatkan kepentingan umum seluas-luasnya (maximizing overall social utility). The economic conception of justice menjadi acuan untuk menilai sampai sejauh mana dampak pemberlakuan suatu ketentuan hukum/peraturan perundang-undangan kepada masyarakat luas. ${ }^{7}$ Pemikiran dari Posner dapat digunakan untuk mengkaji dampak yang mungkin timbul dari pemberlakuan suatu peraturan perundang-undangan yang sedang dipersiapkan. Dalam mengkaji dampak dari peraturan yang akan diberlakukan, mengacu pada tiga elemen dasar yaitu nilai, kegunaan dan efisiensi. Konsep utilitas dapat digunakan untuk melihat manfaat apa yang diperoleh dari suatu pengaturan penilaian, siapa yang yang diuntungkan dan siapa yang dirugikan akibat pemberlakuan aturan tersebut.

Utilitas merupakan istilah ekonomi yang berarti keuntungan atau manfaat (benefit) yang diterima oleh

\footnotetext{
${ }^{5}$ Ibid, hal. 78

${ }^{6}$ Fajar Sugianto, Economic Analysis of Law: Seri Analisis Ke-ekonomian tentang Hukum Seri I Pengantar, Jakarta: Kencana, 2013, hal. 45

${ }^{7}$ Ibid, hal. 45
} 
pengguna dari sesuatu. Perlu disadari bahwa pada kenyataannya sebuah properti memiliki beberapa komponen seperti ruangan, fasilitas, karakter, material, kondisi, lokasi, dan sebagainya; dimana masingmasing menawarkan utilitasnya sendiri-sendiri kepada penggunanya dan utilitas ini dapat berbeda bagi calon pengguna yang berbeda. Terdapat dua hal yang perlu diperhatikan, yaitu:

- Jumlah utilitas yang ditawarkan oleh sebuah properti pada umumnya mempunyai pengaruh langsung terhadap nilai properti yang bersangkutan, dengan catatan bahwa properti tersebut mempunyai demand

- Utilitas akan bervariasi tergantung kepada tipe peminat yang ada; sebagai contoh pasangan menikah akan lebih berminat pada properti dengan jumlah kamar tidur yang lebih banyak daripada seorang yang belum menikah.

Dari hal tersebut, dapat disimpulkan bahwa bagian penting dari proses penilaian adalah mengidentifikasikan jenis dan jumlah peminat atas properti, dan memperhatikan kaitan harga dengan karakter-karakter utama dan properti. Hal lain yang perlu diperhatikan adalah tentang utilitas marginal yang mengacu pada keadaan sebenarnya, bahwa calon pembeli mempunyai batas maksimum keinginan untuk membayar harga karakteristik properti tertentu. Karakteristik tersebut antara lain adalah: besaran properti, baik tanah atau bangunannya. Pada saat seseorang menganggap besaran tertentu atas bangunan atau tanah telah cukup untuk memenuhi kebutuhannya, maka tambahan besaran atas tanah atau bangunan akan mempunyai utilitas yang lebih kecil, dengan demikian akan menurunkan harganya. Karakter properti, mempunyai utilitas marginal pada tahap dimana, calon pembeli tidak mau membayar lebih banyak lagi atas tambahan unit dari jumlah yang sebenarnya dibutuhkan. Hal ini menjadi sangat penting dalam penerapan metode perbandingan; demikian halnya jika menerapkan metode biaya pada suatu properti.

\section{c. Prinsip Substitusi}

Pembeli yang rasional diharapkan mempertimbangkan kemungkinan membeli tanah kosong dan kemudian mendirikan bangunan diatasnya sebagai alternatif dari pembelian properti yang telah siap pakai. Pertimbangan tersebut merupakan perkiraan atas harga tertinggi yang mungkin dibayar atas sebuah properti dan merupakan dasar pemikiran atas penggunaan metode sustitusi biaya sebagai cara lain untuk menentukan nilai properti. Dilihat dan sudut pandang yang lain, pembeli diharapkan akan mempertimbangkan biaya terhadap harga yang mungkin dibayarkan atas properti yang tidak memiliki karakteristik yang mereka inginkan. Hal ini merupakan dasar pemikiran atas penggunaan penyesuaian biaya dalam penerapan metode perbandingan.

Terdapat kelemahan yang serius pada pemikiran ini, yaitu apakah seseorang yang tertarik untukmembeli properti yang telah berdiri, misalnya sebuah gedung perkantoran yang telah berusia 15 tahun, akan wajar untuk membandingkannya dengan biaya pembangunan barunya, kecuali hanya untuk mengetahui bahwa harganya tidak terlalu tinggi? Dalam hal lain, bagaimana kita bisa meyakini bahwa seorang membeli bangunan berdasarkan pada pertimbangan atas biaya penggantinya. Hal ini berarti bahwa pemikiran untuk mengeluarkan penyusutan bangunan danharga jual dapat menghasilkan kekeliruan apabila satu-satunya dasar yang diambil dalam perundingan harga hanyalah sesuatu yang tidak berhubungan secara langsung seperti kualitas aliran pendapatan.

\section{PRINSIP-PRINSIP PENILAIAN.}

Selain konsep Penilaian tersebut di atas, terdapat beberapa prinsip-prinsip Penilaian, antara lain:

\section{a. Prinsip The Highest and Best Use}

Sebelum mengestimasi nilai suatu properti, harus ditentukan keuntungan utama dari properti. Penggunaan yang semaksimal mungkin adalah penggunaan yang akan memberikan keuntungan yang paling maksimal. Ada dua kriteria yang menentukan penggunaan yang semaksimal mungkin, yaitu:

1. Permintaan, baik yang sekarang ada atau yang akan datang dalam waktu yang dekat.

2. Ketentuan mengenai persetujuan untuk peruntukan tipe bangunan yang diizinkan maupun izin-izin yang diperlukan.

\section{b. Prinsip Penawaran dan Permintaan(Principle of Supply and Demand)}

Properti mempunyai nilai bila properti tersebut dapat digunakan. Nilai akan naik bila persediaan tanah berkurang, dimana orang memerlukan tanah. Nilai tanah yang terbaik didapati pada kota dengan penduduk 
yang padat, dimana tanah tersedia sedikit sehingga harga tanah menjadi tinggi dan sulit dipercaya.

\section{c. Prinsip Pengganti (Principle of Subtitution)}

Pembeli suatu properti tidak akan membayar lebih terhadap suatu properti dibandingkan dengan biaya pembelian properti lain yang sama. Misalnya dalam pasar didapat dua properti (rumah baru) dengan kondisi yang sama, maka properti dengan harga yang lebih rendah akan terjual terlebih dahulu.

\section{d. Prinsip Keuntungan YangDiharapkan Proper- ti (Principle of Anticipation)}

Nilai suatu properti adalah harapan akan keuntungan dimasa yang akan datang atas penggunaan properti tersebut. Contoh properti yang menghasilkan pendapatan antara lain hotel, losmen dan sebagainya.

\section{e. Prinsip Adanya Perubahan-perubahan (Principle of Change)}

Properti selalu mengalami berubah, nilai dipengaruhi banyak variabel antara lain jumlah penduduk, perubahan kondisi ekonomi, kontrol pemerintah terhadap properti, pembukaan jalan baru dan perubahan politik negara.

\section{f. Prinsip Kesesuaian (Principle of Conformity)}

Properti yang terletak pada lingkungan yang cocok baik sosial maupun ekonominya, akan mempunyai nilai yang maksimum. Properti yang terletak didaerah yang kurang cocok, nilainya akan lebih kecil.

\section{g. Prinsip Persaingan (Principle of Competition)}

Semua bentuk usaha ingin mendapatkan keuntungan, tidak terkecuali properti.Bila permintaan akan suatu properti besar, developer akan mendapat keuntungan besar. Developer lain akan masuk ke lokasi tersebut, maka timbul persaingan, keuntungan akan turun.

\section{h. Prinsip Penambahan dan Pengurangan Pen- dapatan (Principle of Increasing and Decrea- sing Return)}

Penambahan biaya pada suatu properti belum tentu akan menambah penghasilan properti tersebut. Pada titik tertentu, penambahan biaya tersebut akan mengakibatkan penambahan hasil yang makin berkurang. Nilai properti tersebut tidak bertambah, bahkan akan berkurang/turun.

\section{i. Prinsip Kontribusi (Principle of Contribution)}

Baik tanah maupun bangunan biasanya memberikan kontribusi pada total nilai dari harta kekayaan. Suatu contoh dari bangunan komersial yang sudah tua diatas tanah komersial boleh dikatakan bahwa nilai tanah disini memberikan kontribusi terhadap seluruh nilai properti tersebut.

\section{j. Prinsip Keseimbangan (Principle of Balance)}

Beberapa jenis nilai yang telah dikenal luas diantaranya adalah:

a) Nilai Investasi adalah nilai dari investor tertentu dengan asumsi yang spesifik dari suatu investor.

b) Nilai Guna adalah nilai dari sesuatu aset yang ditentukan berdasarkan kegunaan khusus bagi si pemilik, yang kecil kegunaannya atau tidak berguna bagi pemilik lain.

c) Nilai Taksiran,merupakan nilai properti untuk tujuan perpajakan.

d) Nilai Asuransi, merupakan porsi dari nilai aset yang diakui dalam polis asuransi yang secara umum didasarkan pada nilai penggantian terdepresiasi ataupun biaya reproduksi dari bangunan.

e) Nilai Pasar Wajar, adalah harga yang terja- di dari hasil tawar-menawar antara pembeli dengan penjual.

f) Nilai Sisa, disebut nilai rongsokan, dimana barang dihitung sebagai nilai besi tua.

g) Nilai Sewa, adalah nilai yang ditetapkan untuk mendapatkan hak menggunakan sesuatu harta dalam jangka waktu yang terbatas dan ditetapkan.

h) Nilai Wajar, diartikan sebagai biaya reproduksi baru dikurangi dengan penyusutan yang ada, dengan mempertimbangkan sifat dan kegunaan barang yang bersangkutan, dengan asumsi harta tersebut dilanjutkan penggunaannya sebagai bagian dari perusahaan yang sedang berjalan, tetapi tidak ada hubungann yang bersifat khusus atas pendapatan perusahaan.

i) Nilai Tukar, adalah nilai yang ditentukan dengan membandingkan barang tertentu dengan barang lain yang sebanding. Barang tersebut dan pembandingnya biasanya merupakan barang untuk kegunaan umum lawan dari barang untuk kepentingan khusus. 
j) Nilai Perusahaan Yang Berjalan, adalah nilai keseluruhan atas kegiatan perusahaan yang sedang berjalan, dimana nilai properti merupakan bagian yang tidak terpisahkan dari kegiatan perusahaan tersebut secara keseluruhan.

k) Nilai "Goodwill" adalah bagian dari nilai dari suatu perusahaan yang sedang berjalan, yang melebihi penanaman modal dan merupakan suatu unsur dari nilai perusahaan yang sedang berjalan.

1) Actual Cash Value, diartikan sama dengan Biaya Reproduksi Baru dikurangi penyusutan, tetapi dengan mengesampingkan hal-hal yang khusus digolongkan sebagai "Non Insurable" (pondasi dan instalasi bawah tanah lainnya).

m) Nilai Buku, adalah nilai suatu properti berdasarkan catatan pembukuan, sesudah dikurangi dengan penyusutan dan ditujukan untuk keperluan akuntansi dan/atau perpajakan.

n) Nilai Likuidasi, adalah suatu harga dimana suatu properti akan dijual di pasar terbuka, biasanya dengan suatu keadaan terpaksa untuk dijual dalam batas waktu yang ditentukan.

o) Nilai Modal, adalah nilai yang ditetapkanuntuk mendapatkan hak milik terhadap semua harta.

p) Nilai Penjualan, adalah nilai yang telah ditetapkan oleh pihak penjual untuk tujuan penjualan sesuatu barang.

q) Nilai Potensi, adalah nilai sesuatu barang/ harta berdasarkan potensi pendapatan yang dimiliki oleh barang/harta tersebut pada masa yang akan datang.

r) Nilai Spekulasi, adalah nilai suatu harta tetap berdasarkan kepada prediksi masa datang.

s) Nilai Sentimental, adalah nilai suatu barang yang dipengaruhi perasaan tertentu.

\section{PRAKTEK PENILAIAN HARGA DALAM PERTUKARAN BARANG}

Pemerintah Indonesia memiliki unit di lingkungan Kementerian Keuangan (Pusat Pembinaan Jasa Penilai dan Akuntan) yang bertugas membina profesi Penilai. Disamping itu telah dibentuk unit baru yang juga berada di lingkungan Kementerian Keuangan sebagai pelaksana Penilaian Kekayaan Negara. Unit baru ini bertanggungjawab atas pekerjaan Penilaian Kekayaan Negara dalam rangka optimalisasi pengelolaan Kekayaan Negara. Selanjutnya, pada saat Undang-undang Penilaian terwujud maka kedua unit tersebut perlu terintegrasi kedalam satu unit sebagai lembaga yang bertanggungjawab terhadap sistemPenilaian di Indonesia dengan fungsi membina, mengatur, dan mengawasi. Terhadap fungsi-fungsi tersebut, sebagiannya dilaksanakan oleh Dewan Penilai.

Pada 1990-2000, jasa penilai tidak hanya berperan di lingkungan perbankan, namun ambil bagian dalam perusahaan-perusahaan yang akan go-public. Dalam Undang-Undang Nomor 8 Tahun 1995 tentang Pasar Modal maupun Undang-Undang Nomor 10 Tahun 1998 tentang Perbankan, profesi penilai disebut sebagai profesi penunjang untuk dua institusi keuangan tersebut. Mengingat perbankan dan pasar modal merupakan wahana bagi mobilisasi dana guna menggerakkan roda perekonomian, maka Jasa Penilai dapat membantu perbankan dan pasar modal agar efisien dan sehat.

Jasa Penilai bersama tiga jasa lainnya yaitu jasa akuntan, jasa aktuaria, dan jasa hukum merupakan pilar-pilar penting dalam perekonomian. ${ }^{8}$ Jasa Penilai tugasnya membuat estimasi nilai pasar. Sedang jasa akuntansi menyajikan kekayaan dan kewajiban setiap pelaku usaha secara akurat dan transparan. Demikian pula jasa aktuaria yang memiliki kemampuan menilai risiko, sehingga bermanfaat membantu pemerintah menetapkan langkah-langkah untuk membentuk cadangan pembiayaan serta mengantisipasi kerugian finansial. Selanjutnya, jasa hukum berperan di dalam menciptakan ketertiban dan membantu penegak hukum.

Undang-undang Penilaian tidak hanya mempunyai ruang lingkup yang terbatas pada penilaian atas objek tanah dan atau bangunan (sektor properti), namun juga objek-objek lain dan pada batasan-batasan tertentu akan melingkupi bidang-bidang kegiatan di sektor lain yang memerlukan dukungan jasa penilaian. Secara umum, Penilai telah biasa melakukan kegiatan penilaian yang berkaitan dengan:

a) Konsultansi Properti; b) Studi Kelayakan Bisnis/Investasi; c) Pajak Bumi dan Bangunan d) Pen-

\footnotetext{
${ }^{8}$ lihat Makalah oleh Machfud Sidi., Peran Penilai Dan Usaha Jasa Penilai Dalam Pengelolaan Kekayaan Negara, Makalah Seminar MAPPI, Hotel Borobudur, Jakarta 26-04-2006
} 
gelolaan Kekayaan Negara/Daerah; e) Manajemen Aset; f) Laporan Keuangan Perusahaan; g) Prospektus Investasi; h) Likuidasi; i) Lelang; j) Asuransi; k) Keperluan Ganti Rugi Pembebasan Tanah; 1) Penentuan Tarif Fasilitas Publik; m) Sengketa Hukum atas Properti.

Sejalan dengan perkembangan profesi Penilaian, Indonesia harus merealisasi eksistensi regulasi penilaian dengan landasan hukum, tujuannya mencegah sengketa dalam praktek Penilaian, serta terkait dengan dunia usaha, khususnya pelaporan akuntansi. Saat ini akuntansi telah meninggalkan paradigma lama pelaporan nilai aset dengan mengadopsi nilai wajar. Bila selama ini untuk pencatatan aset, Akuntan menggunakan nilai perolehan, maka saat ini prinsip historical cost mulai bergeser pada pengakuan pada nilai wajar. Dengan adanya Standar terbaru yang dikeluarkan oleh Dewan Standar Akuntansi Keuangan (DSAK) Ikatan Akuntan Indonesia (IAI), Akuntan dapat mencatatkan aktivanya dengan nilai wajar hasil penilaian yang dilakukan oleh Penilai.

Nilai wajar merupakan cerminan dari nilai pasar aset. Bila opini nilai wajar yang dihasilkan oleh Penilai dilakukan secara tepat, tentu saja akan meningkat meningkatkan kualitas Laporan Keuangan. Hal ini karena nilai aset perusahaan benar-benar mencerminkan nilai pasar, sehingga aset perusahaan tidak dilaporkan undervalued ataupun overvalued. Namun di sisi lain hal ini dapat menimbulkan moral hazard dari Penilai, terutama kepentingan Perusahaan untuk menampilkan nilai aset yang besar.

Mengingat peran Penilaian, Pemerintah telah mengatur jasa Penilai sebagaimana tertuang dalam Keputusan Menteri Keuangan No125/PMK.01/2008 tentang Jasa Penilai Publikdan No.406/KMK.06/2004 tentang Usaha Jasa Penilai Berbentuk Perseroan Terbatas. Dalam Keputusan Menteri tersebut, diatur bahwa setiap orang yang melakukan kegiatan penilaian wajib mempunyai kompetensi teknis, memiliki izin praktek, dan mematuhi standar penilaian yang berlaku. Keputusan dimaksud juga merupakan instrumen untuk memacu perkembangan penilai dan asosiasi penilai secara profesional. Pengaturan tentang jasa penilai terkait usaha jasa penilai berbentuk usaha sendiri atau kemitraan.

Standar penilaian merupakan salah satu ukuran yang digunakan dalam menilai kualitas penilaian. Keberadaan Standar Penilaian Indonesia (SPI) seba- gai pedoman bagi Penilai yang tergabung dalam Masyarakat Profesi Penilai Indonesia (MAPPI) selama ini hanya berlaku secara terbatas untuk memenuhi kebutuhan Penilaian namun landasan hukumnya tidak kokoh. SPI tidak berlaku untuk kondisi tertentu sebagaimana secara eksplisit termuat dalam SPI itu sendiri, seperti: a. Penilaian oleh Penilai Internal b. Penilaian untuk Kepentingan Perpajakan c. Penilaian untuk Keperluan Ganti Rugi d. Penilaian dalam rangka pengadaan tanah untuk kepentingan umum.

Dengan adanya batasan-batasan terhadap Standar Penilaian Indonesia, maka SPI tidak dapat menjadi acuan terutama dalam hal-hal yang berkenaan dengan ranah hukum. Sementara itu, terdapat beberapa standar penilaian lain yang berlaku khusus untuk kepentingan tertentu seperti di Direktorat Jende- ral Pajak dan Direktorat Jenderal Kekayaan Negara ataupun di Badan Pertanahan Nasional. Keputusan Menteri Keuangan yang mengatur Penilaian berikut SPI bukan merupakan bagian dari hirarki peraturan perundang-undangan di Indonesia. Hal ini menyebabkan tidak adanya kekuatan mengikat keluar bagi masyarakat secara efektif dan bahkan dalam beberapa peristiwa yang melibatkan lembaga peradilan, SPI dapat diabaikan. Dalam hal ini, pengabaian terhadap standar penilaian dengan sendirinya merupakan penegasian terhadap kaidah-kaidah penilaian yang seharusnya, sehingga justru akan menimbulkan ketidakpastian hukum disebabkan Nilai yang dapat saja diinterpretasikan oleh pihak-pihak lain yang tidak mempunyai kompetensi dalam Penilaian.

Dalam hal ini, pada beberapa kasus penilaian, hasil penilaian yang dilakukan Penilai yang profesional sekalipun harus tunduk pada suatu peraturan yang terkadang tidak sejalan dengan kaidah-kaidah Penilaian yang berlaku secara internasional. Menghadapi fakta yang ada di Indonesia, dalam hal ini penerapan Nilai Jual Objek Pajak (NJOP) sebagai acuan (benchmark) atas Nilai Pasar Tanah dan atau Bangunan secara umum oleh beberapa regulasi sektoral dan dijadikannya NJOP sebagai pedoman penyelesaian persoalan hukum menyangkut Nilai menyebabkan kaidah-kaidah Penilaian menjadi mandul. Adanya regulasi dalam bentuk Undang-Undang yang mengatur Penilaian untuk sektor tertentu telah mengikat masyarakat, namun bila merunut pada prosedur dan kaidah-kaidah profesionalisme Penilai, apa yang diatur berbenturan dengan kaidah Penilaian. 
Selain dari sisi regulasi sektoral yang menjadi kendala pelaksanaan Penilaian secara profesional, ketiadaan regulasi Penilaian akan berpotensi pada lemahnya law enforcement baik kedalam (profesi penilai) maupun keluar (klien/pengguna jasa serta masyarakat lain yang memperoleh dampaknya). Ketidakakuratan dan rendahnya validitas penilaian yang dibuat akan mendistorsi keadilan yang pada gilirannya akan berdampak pada aspek ekonomi, sosial, dan politik berbangsa dan bernegara.

Regulasi Penilaian diperlukan sebagai respon meluruskan ketidak konsistenan regulasi sektoral yang menyentuh Penilaian, serta ditujukan untuk menjawab tuntutan dari semua pihak atas kualitas profesionalisme Penilaian dan selalu berada dalam jalur tata kelola kepemerintahan yang baik dengan berimbangnya peran pemerintah, masyarakat, dan lembaga non-pemerintah. Selanjutnya pengaruh globalisasi dan integrasi Indonesia ke dalam perekonomian internasional juga menuntut regulasi Penilaian guna menempatkan profesionalisme Penilaian Indonesia sejajar dan diakui di level internasional. Dengan kata lain, Indonesia merupakan salah satu negara yang memposisikan sebagai negara yang memiliki standar penilaian internasional yang direalisasikan kedalam undang-undang.

Jiwa dari undang-undang Penilaian di Indonesia akan banyak dipengaruhi oleh standar penilaian yang telah berlaku umum dan elemen-elemen lainnya yang bersifat keindonesiaan dalam konteks Penilaian. Pada pokoknya, undang-undang Penilaian harus menegakkan kaidah-kaidah penilaian yang benar, meningkatkan profesionalisme penilai, melindungi kepentingan pengguna jasa (client), memberikan kewenangan kepada institusi yang akan melakukan fungsi pengawasan/pengaturan, dan memberikan keadilan/kepastian/ manfaat yang sebaik-baiknya bagi masyarakat dan negara secara luas. Eksistensi undang-undang Penilaian juga akan memberi kejelasan dan pemahaman semua pihak yang terkait dengan/dalam praktek penilaian di sektor pemerintah dan sektor swasta (private sector).

\section{RUANG LINGKUP JASA PENILAI DI INDONESIA}

Pasal 10 Keputusan Menteri Keuangan No.406/ KMK.06/2004 mengatur bahwa lingkup kegiatan usaha perusahan Jasa Penilai antara lain meliputi penilaian harta berwujud dan tidak berwujud, penilaian usaha, penilaian proyek, monitoring pembiayaan proyek, konsultasi pengembangan properti, desain sistem informasi aset, pengelolaan properti, dan studi kelayakan usaha. Tiga kegiatan usaha yang disebutkan di awal merupakan kegiatan usaha yang menjadi core business usaha Jasa Penilai, sedang selebihnya merupakan jasa konsultasi yang opsional bisa disediakan oleh usaha Jasa Penilai.

Untuk penilaian harta berwujud maka ruang lingkupnya mencakup penilaian real property, personal property, pabrik, serta mesin. Penilaian real property meliputi penilaian terhadap seluruh manfaat, kepentingan, dan hak dalam kepemilikan terhadap real estat baik mencakup yang komersial dan non komersial, pertanian, industri, residensial, leasing, development right, air right, dan sub surface rights. Penilaian terhadap personal property mencakup penilaian terhadap property yang dapat dipindahkan dan bersifat utilitarian, collectible, decorative atau kombinasi dari ke tiga sifat tersebut. Kegiatan penilaian tersebut sesuai dengan kompetensinya hanya dapat dilakukan oleh Penilai Aset.

Selanjutnya, penilaian usaha merupakan kegiatan atau proses dari menentukan nilai suatu badan usaha atau kepentingan yang melekat dalam kepemilikan suatu badan usaha yang juga mencakup penilaian atas paten, trademarks, copyrights, employment agreement, sekuritas, goodwill, software, assembled workforce dan in-process research and development. Penilai yang kompeten untuk melakukan kegiatan penilaian tersebut adalah penilai berizin yang mempunyai kompetensi di bidang penilaian usaha/bisnis.

Dalam penilaian, seorang penilai properti dapat melakukan penilaian real property, personal property dan mesin dengan tujuan akuisisi ataupun disposisi property, pembiayaan, penutupan asuransi, penyusunan laporan keuangan, serta pembebasan lahan. Sedang seorang Penilai usaha sesuai dengan kompetensi dapat melakukan penilaian dengan tujuan merger dan akusisi, litigasi dan perselisihan kepemilikan perusahaan, employee stock ownershipplans(ESOP), goodwill impairment, buy/sell agreement, regorganisasi dan kepailitan, laporan keuangan, functional obsolescence dan economics ebsolescence. Ruang lingkup penilaian semacam itu merupakan trend yang berkembang saat ini sebagaimana yang dianut oleh 
Appraisal Institutes dan American Society of Appraisal, yang sebagaimana diketahui keduanya merupakan asosiasi profesi penilai terbesar di Amerika Serikat dan mempunyai reputasi tinggi.

\section{JASA PENILAI DAN PENGELOLAAN KEUANGAN/KEKAYAAN NEGARA}

Berdasarkan Undang-Undang Keuangan Negara dan Undang-undang Perbendaharaan Negara serta peraturan pelaksanaannya, menyebabkan Jasa Penilai menempati peran yang penting di dalam pengelolaan keuangan dan kekayaan negara. Peraturan pemerintah yang relevan untuk dikemukakan ada- lah Peraturan Pemerintah No.24 tahun 2005 tentang Standar Akuntansi Pemerintahan (SAP), Peraturan Pemerintah No.57 tahun 2005 tentang Sistem Informasi Keuangan Daerah (SIKD), Peraturan Pemerintah No.58 tahun 2005 tentang Pengelolaan Keuangan Daerah, dan Peraturan Pemerintah No.6 tahun 2006 tentang Pengelolaan Barang Milik Negara/Daerah.

Ketentuan Peraturan Pemerintah No.24 tahun 2005 menentukan bahwa setiap entitas pelaporan pemerintah pusat dan pemerintah daerah wajib menerapkan Standar Akuntansi Pemerintah. Sedang yang dimaksud dengan entitas pelaporan adalah pemerintah pusat dan pemerintah daerah, yaitu satuan organisasi di lingkungan pemerintah pusat/daerah atau organisasi lainnya, jika menurut peraturan perundang-undangan satuan organisasi dimaksud wajib menyajikan laporan keuangan. Dalam ketentuan $\mathrm{Pa}-$ sal 37 Peraturan Pemerintah No.6 tahun 2006 tentang Pengelolaan Barang Milik Negara/Daerah dinyatakan bahwa penilaian barang milik negara/daerah dilakukan dalam rangka penyusunan neraca pemerintah pusat/derah, pemanfaatan, dan pemindahtanganan barang milik negara/daerah. Dalam pelaksanaannya, penilaian tersebut dilakukan oleh tim yang ditetapkan oleh pengelola barang dan dapat melibatkan penilai independen yang ditetapkan oleh pengelola barang.

\section{KESIMPULAN}

Penilaian yang dilakukan selama ini berkaitan dengan Konsultansi Properti, Studi Kelayakan Investasi, Pajak Bumi dan Bangunan, Pengelolaan Kekayaan Negara/Daerah, Manajemen Aset, Laporan Keuangan Perusahaan, Prospektus Investasi di Pasar Modal, Likuidasi, Lelang, Asuransi, Keperluan Ganti Rugi Pembebasan Tanah, Penentuan Tarif Fasilitas Publik, Sengketa Hukum atas Properti. Namun selain sektor tersebut di atas, sebenarnya masih banyak yang perlu dilakukan penilian terhadap sektor-sektor lain terkait dengan perekonomian.

\section{SARAN}

Perlunya suatu peraturan perundang-undangan khusus yang mengatur objek-objek penilaian dan penentuan orang-orang yang dipandang berkompeten melakukan penilaian atas objek-objek tersebut. 
Jurnal Hukum tô-râ, Vol. 1 No. 2, Agustus 2015

\section{Daftar Pustaka}

\section{Buku:}

Ali, Achmad, Menguak Teori Hukum (Legal Theory) \& Teori Peradilan (Judicialprudence): Termasuk Inter- pretasi Undang-Undang (Legisprudence) Volume I Pemahaman Awal, Jakarta: Kencana, 2009

Cooper, John L. Course-packet Modul 2 on Indonesia-Australia Training Specialist Phase II AusAID, Works- hop on Asset Appraisal for Financial Restructuring, Jakarta, 2002. hal. 2 yang dalam versi aslinya menyebutkan: "The theory of valuation is a pragmatic extension of economic tehories relating to value and price, but it is remarkable to find that there is an almost complete dissociation between economic theory and the theory of valuation"

Sugianto, Fajar, Economic Analysis of Law: Seri Analisis Ke-ekonomian tentang Hukum Seri I Pengantar, Jakarta: Kencana, 2013

\section{Undang-Undang:}

- Undang-undang Nomor 12 Tahun 1985 tentang Pajak Bumi dan Bangunan;

- Undang-Undang Nomor 8 Tahun 1995 tentang Pasar Modal;

- Undang-Undang Nomor 10 Tahun 1998 tentang Perbankan;

- Peraturan Pemerintah No.24 tahun 2005 tentang Standar Akuntansi Pemerintahan (SAP); Peraturan Pemerintah No.57 tahun 2005 tentang Sistem Informasi Keuangan Daerah (SIKD); Peraturan Pemerintah No.58 tahun 2005 tentang Pengelolaan Keuangan Daerah;

- Peraturan Pemerintah No.6 tahun 2006 tentang Pengelolaan Barang Milik Negara/Daerah;

- Keputusan Menteri Perdagangan No.161/Kp/1977 yang mengatur perizinan usaha penilai di Indonesia.

- Keputusan Menteri Keuangan No125/PMK.01/2008 tentang Jasa Penilai Publik. Keputusan Menteri Keuangan No.406/KMK.06/2004 tentang Usaha Jasa Penilai Berbentuk Perseroan Terbatas. 